\title{
AKIBAT HUKUM PENGGUNAAN LOGO PERUSAHAAN PT PERTAMINA (PERSERO) OLEH PELAKU USAHA PENJUAL BAHAN BAKAR MINYAK PERTAMINI DI KOTA DENPASAR
}

\author{
Kadek Dewi Darmayanti, I Nyoman Putu Budiartha, Ni Made Puspasutari Ujianti \\ Fakultas Hukum Universitas Warmadewa, Denpasar-Bali, Indonesia \\ kadekdarmayanti1999@gmail.com, budiarthaputu59@gmail.com, puspasutari niwapong@gmail.com
}

\begin{abstract}
Abstrak
Kebutuhan Bahan Bakar Minyak yang sangat tinggi pada Kota Denpasar dinilai sebagai peluang usaha yang memberikan keuntungan yang besar Dalam kegiatan usaha penjualan Bahan Bakar Minyak Pertamini pelaku usaha menggunakan logo milik PT Pertamina untuk memikat konsumen Penggunaan logo yang sama dengan PT Pertamina tidak dibenarkan karena tidak memiliki izin atau lisensi dari pemilik merek Metode penelitian dalam penulisan ini menggunakan penelitian empiris Penulis membahas dua permasalahan hukum yaitu terkait keabsahan penggunaan logo perusahaan PT Pertamina (Persero) terhadap logo usaha dagang penjual bahan bakar minyak di Kota Denpasar dan sanksi yang dikenakan terhadap pelaku usaha penjual bahan bakar minyak Pertamini tersebut Berdasarkan hasil data yang diperoleh menunjukkan bahwa Pertamini tidak memiliki izin dari PT Pertamina untuk menggunakan logo tersebut dan sebagian besar pelaku usaha Pertamini tidak memiliki izin usaha sehingga demikian pelaku usaha Pertamini dapat dikenakan sanksi pidana penjara paling lama 5 (lima) tahun dan/atau denda paling banyak Rp 2.000.000.000.00 (Dua Miliar Rupiah) Pasal 100 ayat (1) Undang-Undang Nomor 20 Tahun 2016 tentang Merek dan Indikasi Geografis.
\end{abstract}

Kata Kunci: Bahan Bakar Minyak, Logo Pertamini, PT Pertamina

\begin{abstract}
The very high demand for fuel oil in Denpasar City is considered as a business opportunity that provides big profits. In the business activities of selling First Oil Fuel, business actors use the logo owned by PT Pertamina to attract consumers. The use of the same logo as PT Pertamina is not justified because it does not have a license. or a license from the brand owner. The research method in this writing uses empirical research. The author discusses two legal issues, namely the validity of the use of the PT Pertamina (Persero) company logo on the logo of the fuel oil seller trading business in Denpasar City and the sanctions imposed on fuel selling business actors. Based on the results of the data obtained, it shows that Pertamini does not have a permit from PT Pertamina to use the logo and most of the Pertamini business actors do not have a business license so that the Pertamini business actors can be a maximum imprisonment of 5 (five) years and / or a maximum fine of IDR 2,000,000,000.00 (Two Billion Rupiah) Article 100 paragraph (1) of Law Number 20 of 2016 concerning Marks and Geographical Indications.
\end{abstract}

Keywords: Fuel Oil, Pertamini Logo, PT Pertamina

\section{PENDAHULUAN}

Meningkatnya jumlah pengguna sepeda motor khususnya pada Kota Denpasar mengakibatkan penggunaan Bahan Bakar Minyak juga terus mengalami peningkatan. Kebutuhan atas BBM yang sangat tinggi dinilai sebagai peluang usaha yang menjanjikan dan dapat memberikan keuntungan yang besar. Pertamini merupakan suatu jenis kegiatan usaha penjualan Bahan Bakar Minyak eceran yang dikemas secara modern dengan menggunakan alat pompa dan tabung takaran dan ada juga yang dilengkapi dengan dispenser otomatis seperti SPBU milik PT Pertamina. Menurut Riyasti \& Subawa (2014), pertamini merupakan nama merek yang menyerupai PT. Pertamina. Namun diketahui bahwa Pertamini yang dimiliki oleh sebagian besar masyarakat merupakan mesin yang bersifat tidak sah secara hukum.

Banyaknya pelaku usaha yang melakukan segala cara demi mendapatkan keuntungan yang lebih dengan cara menggunakan logo milik PT Pertamina untuk memikat konsumen. Perlu diketahui bahwa penggunaan logo milik perusahaan lain secara ilegal tanpa adanya izin dari pemilik merek hal tersebut membuat para pelaku usaha pertamini melakukan suatu pelanggaran hukum dan sebagian besar Pertamini yang dimiliki oleh pelaku usaha merupakan mesin yang bersifat tidak sah secara hukum. 
Sebagai contoh di Kota Denpasar masih banyaknya pelaku usaha penjual Bahan Bakar Minyak Pertamini yang menggunakan logo PT Pertamina dalam kegiatan usahanya Logo milik PT Pertamina merupakan Hak Paten yang telah resmi dimiliki oleh PT Pertamina dan telah terdaftar dan tidak dapat digunakan oleh pihak manapun tanpa izin dari pemilik merek. Sebagian besar masyarakat beranggapan bahwa Pertamini adalah singkatan dari Pertamina versi mini dan Pertamini itu milik PT Pertamina padahal dalam kenyataannya Pertamini itu bukan bagian dari PT Pertamina dan bukan anak perusahaan dari Pertamina Mengisi Bahan Bakar Minyak di Pertamini memiliki berbagai dampak dan yang paling berbahaya adalah sepeda motor bisa hangus terbakar saat pengisian Bahan Bakar Minyak di Pertamini karena Pertamini tidak berafiliasi dengan PT Pertamina dan Pertamini tidak mengikuti standarisasi seperti SPBU Pertamina.

Logo adalah lambang gambar berupa huruf atau sebagainya yang mencerminkan suatu kata dalam label perusahaan dan sebagainya (Indra, 2000). Logo dan warna Pertamina merupakan Hak Paten yang sudah dimiliki PT Pertamina dan telah didaftarkan pada Direktorat Jenderal Kekayaan Intelektual (Ditjen KI) Kementerian Hukum dan Hak Asasi Manusia (Kemenkumham) dan telah resmi pada tanggal 10 Desember 2005. Apabila ada masyarakat yang menjual Bahan Bakar Minyak mengikutsertakan logo dan warna tanpa izin dari Pertamina maka itu sudah melanggar hukum dan pihak Pertamina bisa menuntut pemilik Pertamini yang menggunakan warna dan logo Pertamina. Oleh karena itu, penelitian ini bertujuan untuk mengetahui Keabsahan Penggunaan Logo Perusahaan PT Pertamina (Persero) Terhadap Logo Usaha Dagang Penjual Bahan Bakar Minyak di Kota Denpasar dan mengetahui Sanksi Yang Dikenakan Terhadap Pelaku Usaha Penjual Bahan Bakar Minyak Pertamini Di Kota Denpasar.

Sejumlah penelitian serupa pernah dikaji, diantaranya mengenai penggunaan logo pertamina oleh pelaku usaha penjualan bbm pertamini tanpa izin pemegang hak merek (Pratiwi, Firdaus, \& Bachtiar, 2018), lainnya mengenai tinjauan yuridis tentang fenomena pertamini dalam praktik distribusi BBM untuk masyarakat (Zamroni, 2018), dan terakhir mengenai pengawasan terhadap penjualan Bahan Bakar Minyak (BBM) Pertamini dalam hukum Ekonomi Islam (Lestari, 2019).

\section{METODE PENELITIAN}

Metode penelitian yang digunakan adalah empiris yang dimana jenis penelitian lapangan yang mengkaji ketentuan hukum yang berlaku serta apa yang terjadi dalam kenyataan di masyarakat (Waluyo, 2002) dengan pendekatan sosiologis hukum pendekatan Undang-Undangan dan pendekatan konseptual. Ada beberapa sumber baik data primer maupun sekunder (Soekanto \& Mamudji, 2001) yang digunakan seperti Undang-Undang Nomor 20 Tahun 2016 Tentang Merek dan Indikasi Geografis Undang-Undang Nomor 8 Tahun 1999 Tentang Perlindungan Konsumen Undang-Undang Nomor 22 Tahun 2001 Tentang Migas dan Kitab Undang-Undang Hukum Pidana Selain itu juga terdapat hasil penelitian dengan wawancara kepada pihak terkait yaitu pelaku usaha Pertamini Disperindag serta Kepala Desa di Kota Denpasar dan terjun langsung ke lapangan sebagai data primernya.

\section{HASIL DAN PEMBAHASAN}

\section{Keabsahan Penggunaan Logo Perusahaan PT Pertamina (Persero) terhadap Logo Usaha Dagang Penjual Bahan Bakar Minyak Pertamini}

Logo milik Pertamina merupakan logo resmi dan telah memiliki Hak Atas Merek yang telah terdaftar pada Direktorat Jenderal Kekayaan Intelektual dan Hak Merek Atas logo perusahaan yang telah terdaftar tersebut hanya dapat digunakan oleh pemilik merek ataupun pihak lain berdasarkan perjanjian tertulis (lisensi) dan mempergunakan merek terdaftar tanpa hak yang sah pengguna merek tersebut dapat dikenakan sanksi pidana dan Pertamina mempunyai hakikat perlindungan hukum Berdasarkan hasil wawancara dengan beberapa pelaku usaha Bahan Bakar Minyak (BBM) Pertamini yang berada di Kota Denpasar dapat diketahui bahwa sebagian besar para pelaku usaha tidak memiliki izin usaha untuk pendirian usaha Pertamini dan pengaturan pengisian serta penyimpanan Bahan Bakar Minyak tersebut tidak sesuai dengan standar dari Pertamina hal tersebut dapat membahayakan serta merugikan konsumen Serta dalam kegiatan usaha Bahan Bakar Minyak (BBM) eceran yang mereka jalankan menggunakan logo yang telah terdaftar milik PT Pertamina.

Berdasarkan wawancara dengan beberapa Kepala Desa dan Lurah di Kota Denpasar memberikan penjelasan bahwa Pertamini tidak mendapatkan izin usaha dari desa tetapi ada sebagian desa yang 
memberikan rekomendasi untuk izin usaha tetapi tidak untuk penjualan Pertamini melainkan usaha toko tersebut Dan berdasarkan informasi dari Dinas Perindustrian dan Perdagangan (Disperindag) menyatakan bahwa Disperindag tidak pernah melakukan sidak terhadap pelaku usaha Pertamini meskipun illegal karena itu wewenang Pertamina Pertamini dengan bermodal nekat tanpa adanya izin dan Pertamini juga usaha yang ilegal karena tidak adanya izin usaha.

Secara hukum, logo milik PT Pertamina adalah logo yang sudah terdaftar dan telah disahkan secara resmi tertanggal 10 Oktober 2005 pada Direktorat Hak Cipta Desain Industri Desain Tata Letak sirkuit Terpadu dan Rahasia Dagang Departemen Hukum dan HAM RI Pemilik merek terdaftar dapat memberikan lisensi kepada pihak lain untuk menggunakan merek tersebut baik sebagian maupun seluruh jenis barang dan/atau jasa Lisensi adalah izin yang diberikan oleh pemilik merek terdaftar kepada pihak lain berdasarkan perjanjian secara tertulis sesuai peraturan perundang-undangan untuk menggunakan merek terdaftar.

Dalam hal ini para pelaku usaha penjual Bahan Bakar Minyak (BBM) Pertamini melakukan suatu pelanggaran atau tidak memiliki hak untuk menggunakan logo milik PT Pertamina karena tidak adanya izin dari Pertamina untuk mempergunakan logo perusahaan milik PT Pertamina tersebut karena hanya merek terdaftar yang berhak atas perlindungan hukum dari negara kata terdaftar disini memiliki arti telah melalui tahap permohonan pemeriksaan formalitas proses pengumuman dan proses pemeriksaan substantif serta mendapatkan persetujuan Menteri untuk diterbitkan sertifikat Secara tidak langsung pelaku usaha penjual Bahan Bakar Minyak (BBM) Pertamini telah menimbulkan kerugian bagi Pertamina dan Konsumen Dalam hal ini Konsumen dirugikan karena standar keamanan yang diberikan oleh para pelaku usaha Pertamini tidak memenuhi SNI (Standar Nasional Indonesia) yang dimana dapat berakibat fatal yaitu kebakaran dan Bahan Bakar Minyak (BBM) yang dijual oleh Pertamini tidak terjamin mutunya bahkan ada yang takarannya dikurangi demi mendapatkan keuntungan yang lebih Dan jika dilihat dari sisi materil Pertamina dirampas haknya oleh Pertamini karena mempergunakan Hak Merek yang dimiliki PT Pertamina sedangkan secara moril masyarakat akan berasumsi bahwa Pertamini memiliki hubungan kerja sama dengan pihak Pertamina karena memakai logo dari Pertamina yang akan mencoreng nama perusahaan Pertamina sebagai perusahaan besar Internasional Persaingan tidak jujur tersebut dilakukan oleh pengusaha yang beritikad baik itu dengan cara memproduksi barang-barang dengan menggunakan merek yang sudah dikenal secara luas dalam masyarakat yang bukan merupakan haknya (Saidin, 2004), maka pihak Pertamina berhak untuk melarang siapapun untuk menggunakan merek yang sama dengan merek terdaftar miliknya dan dapat pula mengajukan gugatan terhadap Pertamini atas penggunaan logo secara ilegal tersebut Pertamina juga memiliki hak untuk mengajukan gugatan pembatalan terhadap merek terdaftar lainnya yang mempunyai persamaan pada pokoknya atau keseluruhannya dengan merek terdaftar tersebut ke Pengadilan Niaga dan berhak mengajukan gugatan ganti rugi atau penghentian semua perbuatan yang berkaitan dengan penggunaan merek tersebut berdasarkan Undang-Undang Nomor 20 Tahun 2016 Tentang Merek dan Indikasi Geografis.

\section{Sanksi Yang Dikenakan Terhadap Pelaku Usaha Penjual Bahan Bakar Minyak Pertamini Di Kota Denpasar}

Dengan adanya persamaan antara SPBU Pertamina dengan pedagang minyak eceran Pertamini konsumen beranggapan bahwa penjual bahan bakar minyak Pertamini adalah salah satu usaha milik Pertamina Berdasarkan fakta yang telah didapatkan dengan cara berwawancara dengan para pelaku usaha dagang Pertamini di Kota Denpasar adalah para pelaku usaha dagang Pertamini di Kota Denpasar sebagian besar tidak memiliki izin usaha serta tidak memiliki wewenang untuk menjual bahan bakar minyak Pertamini Pada dasarnya Pertamini memiliki kesamaan dengan SPBU yang dimiliki oleh Pertamina baik dari warna logo dan jenis BBM yang dijual Pedagang minyak eceran. Pertamini juga terindikasi menyalahi peraturan yang berlaku dalam Undang- Undang Nomor 22 Tahun 2001 tentang Minyak dan Gas Bumi karena mereka tidak memiliki izin resmi serta mencari keuntungan dari penjualan Bahan Bakar Minyak (BBM) yang disubsidi oleh pemerintah.

Dalam menjalankan usahanya para pelaku usaha dagang Pertamini menggunakan logo resmi milik PT Pertamina didasarkan oleh beberapa factor, yaitu:

1. Faktor Kesengajaan Pelaku Usaha penggunaan logo resmi milik PT Pertamina oleh pelaku usaha dagang Bahan Bakar Minyak (BBM) Pertamini dilatar belakangi oleh beberapa faktor salah satunya adalah faktor kesengajaan dari pelaku usaha Kesengajaan dapat diartikan 
sebagai menghendaki dan mengetahui Artinya seseorang yang melakukan suatu tindakan dapat dikatakan sengaja apabila menghendaki serta mengetahui tindakan dan/atau akibatnya Fakta yang terjadi di masyarakat penggunaan logo milik PT Pertamina oleh pelaku usaha dilakukan secara sengaja dan sadar oleh pelaku usaha Hal ini tergambar melalui hasil wawancara terhadap beberapa pelaku usaha yang menjalankan usahanya di wilayah Kota Denpasar Salah satunya wawancara yang dilakukan penulis dengan Bapak Sujibno mengenai penggunaan logo dalam usaha dagang Pertamini bahwa Bapak Sujibno mengetahui logo yang dipakai dalam usaha dagang Pertamini nya tersebut adalah logo resmi PT Pertamina Dari hasil wawancara tersebut membuktikan bahwa Bapak Sujibno sebagai pelaku usaha secara sadar melakukan tindakan tersebut Apabila melihat fakta-fakta yang terjadi berdasarkan hasil wawancara yang telah dilakukan maka tindakan yang dilakukan oleh pelaku usaha tersebut dilakukan secara sengaja dan memiliki tujuannya masing-masing yang ingin dicapai.

2. Keinginan Pelaku Usaha Dagang Bahan Bakar Minyak (BBM) Pertamini Memperoleh Keuntungan/Laba kesengajaan pelaku usaha dalam menggunakan logo milik PT Pertamina dalam kegiatan usahanya juga didorong oleh berbagai faktor lain salah satunya faktor yang mendorong kesengajaan oleh pelaku usaha tersebut adalah keinginan dari pelaku usaha untuk memperoleh keuntungan/laba hal ini diperoleh dari hasil wawancara kepada beberapa pelaku usaha Pertamini yaitu kepada salah satu pemilik toko Bapak Assyarif mengungkapkan bahwa hal tersebut dilakukan demi meningkatkan keuntungan yang diperoleh dari penggunaan logo milik PT Pertamina tersebut Meskipun hal tersebut relevan dengan tujuan bisnis tetapi itu merupakan cara yang kurang tepat untuk memperoleh keuntungan dengan menggunakan logo resmi milik PT Pertamina.

3. Rendahnya tingkat pengetahuan konsumen dan pelaku usaha penggunaan logo milik PT Pertamina oleh pelaku usaha Pertamini yang terjadi di masyarakat sangat dipengaruhi oleh tingkat pengetahuan yang dimiliki oleh konsumen ataupun pelaku usaha Pengetahuan didefinisikan sebagai informasi yang dimiliki seseorang dalam bidang spesifik (Purnamasari \& Hernawati, 2013).

Masih banyaknya masyarakat yang tidak mengetahui mengenai peraturan- peraturan yang mengatur tentang logo atau merek pengakuan tersebut beberapa kali ditemukan dalam wawancara dengan konsumen dan pelaku usaha salah satunya pengakuan yang diberikan oleh Bapak Jazuli berkaitan dengan peraturan mengenai logo beliau memberikan komentarnya bahwa beliau tidak mengetahui mengenai aturan-aturan tersebut karena semuanya memakai logo milik Pertamina jadi beliau ikut memakai Berdasarkan pengakuan dari Bapak Jazuli dapat diketahui bahwa fakta-fakta yang terjadi di masyarakat bahwa penggunaan logo PT Pertamina oleh pelaku usaha Pertamini masih terus berlangsung bahkan semakin banyak yang melakukan hal tersebut. Alasan pelaku usaha memakai merek atau dalam hal ini logo yang mirip dengan Pertamina tentunya berharap bahwa dengan adanya kemiripan tersebut dapat memperoleh keuntungan yang besar tanpa mengeluarkan biaya besar untuk promosi memperkenalkan produksinya Sanksi merupakan akibat hukum bagi pelanggar ketentuan Undang-Undang ada sanksi administratif ada sanksi perdata dan ada sanksi pidana (Hamzah, 2008). Sebagaimana diatur dalam Pasal 100 ayat (1) Undang-Undang Nomor 20 Tahun 2016 tentang Merek dan Indikasi Geografis menyatakan bahwa setiap orang yang dengan tanpa hak menggunakan merek yang sama pada keseluruhannya dengan merek terdaftar milik pihak lain untuk barang dan/atau jasa sejenis yang diproduksi dan/atau diperdagangkan dipidana dengan pidana penjara paling lama 5 (lima) tahun dan/atau pidana denda paling banyak Rp. 2.000.000.000.00 (Dua Miliar Rupiah).

Sanksi yang dapat dijatuhkan oleh pelaku usaha yang melakukan pelanggaran merek selain dari Undang-Undang Nomor 20 Tahun 2016 Tentang Merek dan Indikasi Geografis pemakaian merek tanpa hak dapat digugat berdasarkan perbuatan melanggar hukum Pasal 1365 KUH Perdata sebagai pihak penggugat harus membuktikan bahwa ia karena perbuatan melanggar hukum tergugat menderita kerugian Pasal 83 ayat (1) Undang-Undang Nomor 20 Tahun 2016 Tentang Merek dan Indikasi Geografis sanksi pidana terhadap tindakan yang melanggar hak seseorang di bidang merek selain diatur khusus dalam ketentuan sanksi peraturan perundang-undangan merek itu sendiri juga terdapat dalam ketentuan KUHP Persaingan tidak jujur dengan sendirinya bersifat melawan hukum karena hukum memberikan perlindungan terhadap pergaulan yang tertib dalam dunia usaha.

Bila terjadi pelanggaran terhadap hak intelektual negara juga bisa menggunakan kekuasaannya untuk melindungi pemilik yang sah melalui kewenangan administrasi negara yaitu diantaranya 
melalui pabean standar industri kewenangan Pengawasan Badan Penyiaran kewenangan Pengawasan Standar Periklanan (Hidayati, 2011).

\section{SIMPULAN DAN SARAN \\ 1. Simpulan}

Keabsahan penggunaan logo perusahaan PT Pertamina (Persero) terhadap logo usaha dagang penjual bahan bakar minyak adalah Logo perusahaan yang telah terdaftar hanya dapat digunakan oleh pemilik merek ataupun pihak lain berdasarkan perjanjian secara tertulis (lisensi) dan penggunaan merek terdaftar tanpa hak yang sah penggunaan merek tersebut dapat dikenakan sanksi pidana Dalam hal ini para pelaku usaha penjual Bahan Bakar Minyak (BBM) Pertamini melakukan suatu pelanggaran dan tidak memiliki hak untuk menggunakan logo milik PT Pertamina karena tidak adanya izin dari Pertamina Pertamina berhak untuk melarang siapapun untuk menggunakan merek yang sama dengan merek terdaftar miliknya dan dapat mengajukan gugatan terhadap pertamini sesuai dengan pasal 83 Undang-Undang Nomor 20 Tahun 2016 Tentang Merek dan Indikasi Geografis.

Kemudian, sanksi pidana yang dapat dikenakan bagi pelaku usaha penjual Bahan Bakar Minyak Pertamini terkait penggunaan logo milik PT Pertamina yang memiliki kesamaan pada pokoknya adalah pelaku usaha Pertamini dapat dikenakan sanksi pidana penjara paling lama 5 (lima) tahun dan/atau denda paling banyak Rp 2.000.000.000.00 (dua miliar rupiah) karena telah memenuhi unsur-unsur sebagaimana dimaksud pada Pasal 100 ayat (1) Undang-Undang Nomor 20 Tahun 2016 Tentang Merek dan Indikasi Geografis Pelaku usaha Pertamini juga harus menghentikan segala perbuatan yang berkaitan dengan penggunaan Logo milik PT Pertamina karena tidak memiliki hak yang sah dalam penggunaan logo tersebut Jika dalam hal ini pelaku usaha Pertamini tidak menghentikan segala perbuatannya maka pemilik merek dapat mengajukan gugatan berupa gugatan ganti rugi dan gugatan penghentian segala perbuatan yang berkaitan dengan penggunaan logo/merek sebagaimana diatur dalam Pasal 83 ayat (1) selain itu Ditjen KI juga akan melakukan penolakan merek jika pelaku usaha Pertamini melakukan pendaftaran pada merek tersebut.

\section{Saran}

Melalui penelitian ini diharapkan kepada Pemerintah hendaknya pemerintah memberikan sanksi yang tegas kepada pelanggar hak atas merek dalam hal ini pelaku usaha penjual Bahan Bakar Minyak (BBM) Pertamini yang menggunakan logo orang lain untuk melakukan penjualan barang/jasa Melakukan edukasi bagi masyarakat khususnya para pelaku usaha Pertamini Serta melakukan penerapan perlindungan secara preventif untuk mencegah adanya penerapan pelanggaran hak atas merek. Selanjutnya, kepada PT Pertamina (Persero) melakukan tindakan yang lebih tegas agar pelaku usaha penjual Bahan Bakar Minyak (BBM) Pertamini tidak lagi menggunakan logo dari PT Pertamina (Persero). Kepada para pelaku usaha penjual Bahan Bakar Minyak (BBM) Pertamini mencari informasi terkait peraturan-peraturan yang telah ada sebelum menggunakan logo atau merek yang akan dipakai dalam kegiatan usaha. Kepada konsumen agar bisa memilih tempat membeli Bahan Bakar Minyak (BBM) yang sesuai dengan standar yang berlaku

\section{DAFTAR PUSTAKA}

Hamzah, A. (2008). Terminologi Hukum Pidana (Tarmizi, Ed.). Jakarta: Sinar Grafika.

Hidayati, N. (2011). Perlindungan Hukum Bagi Merek Yang Terdaftar Ragam. Ragam Jurnal Pengembangan Humaniora, 11(3).

Indra, S. (2000). Kamus Praktis Bahasa Indonesia. Surabaya: Pustaka Dua.

Lestari, N. I. Y. (2019). Pengawasan terhadap Penjualan Bahan Bakar Minyak (BBM) Pertamini dalam Hukum Ekonomi Islam (Studi di Kecamatan Tembelang Kabupaten Jombang). Universitas Islam Negeri Maulana Malik Ibrahim Malang.

Pratiwi, S., Firdaus, \& Bachtiar, M. (2018). Penggunaan Logo Pertamina oleh Pelaku Usaha Penjualan BBM Pertamini tanpa Izin Pemegang Hak Merek. JOM Fakultas Hukum Universitas Riau, V(2).

Purnamasari, D., \& Hernawati, E. (2013). Pengaruh Etika Auditor Pengalaman Pengetahuan dan Perilaku Disfungsional Terhadap Kualitas Audit. Jurnal Berkala Jemu Ekonomi, 7(2).

Riyasti, N. M. W., \& Subawa, I. M. (2014). Tanggung Jawab Pelaku Usaha Pertamini Sebagai Penjual Bahan Bakar Minyak Eceran di Kota Denpasar. Kertha Semaya, 4(1).

Saidin, O. (2004). Aspek Hukum Hak Kekayaan Intelektual. Jakarta: Raja Grafindo Persada.

Soekanto, S., \& Mamudji, S. (2001). Penelitian Hukum Normatif: Suatu Tinjauan Singkat. Jakarta: PT. Raja 
Jurnal Interpretasi Hukum

Vol. 2, No. 1, 2021

Grafindo Persada.

Waluyo, B. (2002). Penelitian Hukum dalam Praktek. Jakarta: Sinar Grafika.

Zamroni, M. (2018). Tinjauan Yuridis tentang Fenomena Pertamini dalam Praktik Distribusi BBM untuk Masyarakat (Studi di Kota Semarang). Universitas Negeri Semarang. 